\title{
Correlation between Carbohydrate, Protein and Fat Intake with Serum C-Reactive Protein Level in Lung Cancer Patients Stage IIIB- IV
}

Received $28^{\text {th }}$ November 2017,

Accepted $22^{\text {th }}$ January 2018

Link to DOI:

10.25220/WNJ/V01.i2.0006

Journal Website: www.worldnutrijournal.org

\author{
Patricia Amanda, ${ }^{1}$ Diana Sunardi, ${ }^{1}$ Noorwati Sutandyo, ${ }^{2}$ \\ 1. Department of Nutrition Medical Faculty Universitas Indonesia - Cipto Mangungkusumo General \\ Hospital \\ 2. Departement of Internal Medicine, Medical Faculty Universitas Indonesia, Dharmais Cancer \\ Hospital
}

\begin{abstract}
Introduction: The aim of the study is to determine the correlation between carbohydrates, fat and protein intake with the serum C-Reactive-Protein level in lung cancer patients stage IIIB - IV. The progression of lung cancer is influenced by immune system, genetic factors and inflammatory response, therefore CRP can be relied as one of the parameters for predicting cancer cell growth. Methods: A cross sectional study was conducted in Dharmais Cancer Hospital Jakarta. Subjects were recruited by consecutive sampling, 49 subjects with lung cancer stage IIIB-IV who currently not receiving any treatment in Dharmais Hospital participating in this study.

Results: The mean age of subject was $55.82 \pm 12.26$ years old and $63.3 \%$ were male. The median value of CRP is $23.82(0.30-207.29) \mathrm{mg} / \mathrm{L}$. The correlation between carbohydrate, protein and fat intake with serum CRP level $(r=0.015$ and $p=0.919 ; r=-0.165$ and $p=0.257 ; r=0.003$ and $p=0.986$, respectively).

Conclusion: This study did not show significant correlation between carbohydrate, protein and fat intake with serum CRP level. In further analysis we did found that there was a negative, but nonsignificant correlation between protein intake and serum CRP level in cancer patient stage IV, as well as fat intake and serum CRP level.
\end{abstract}

Keywords C-Reactive-Protein, Inflammation, Lung Cancer, Carbohydrate intake, Protein Intake and Fat Intake

\section{Introduction}

Cancer is one of the non-communicable diseases with high incidence rates and the leading cause of death worldwide. Lung cancer is a type of cancer with the highest incidence and the leading cause of death from cancer in men. ${ }^{1}$ Based on data from the

\footnotetext{
Corresponding author:

Patricia Amanda

Department of Nutrition Medical Faculty, Universitas Indonesia - Cipto Mangunkusumo General Hospital

Email address :my.whitelily.87@gmail.com
}

Department of Pulmonology and Respiratory Medicine at the Faculty of Medicine University of Indonesia - Persahabatan General Hospital, the incidence of lung cancer has increased more than five-folds in the last 10 years, and most patients come at an advanced stage (IIIB/IV). ${ }^{2}$ Malnutrition is a frequent manifestation in cancer patient and can negatively affect the outcome of treatments, thus a significant contributor to morbidity and mortality. ${ }^{3}$ Studies have demonstrated that $30 \%$ to $87 \%$ of cancer patients are diagnosed with malnutrition. ${ }^{4}$ 
Malnutrition in cancer patient is multifactorial and can be contributed to several factors: local effects of a tumor, the host response to the tumor, anticancer therapies, reduced food intake due to systemic effects of the disease, local tumor effects, psychological effects or adverse effects of treatment, and alterations in nutrient metabolism and resting energy expenditure (REE). ${ }^{5}$ The interactions between cancer cells and normal host cells form a tumor microenvironment that causes changes in carbohydrate, protein and fat metabolism in the host body. ${ }^{6}$ Metabolic changes that occur aim to provide the supply of energy and substrate that support the rapid growth of cancer cells. ${ }^{7}$ Nearly a century, Otto H Warburg stated that cancer cells take glucose from their surroundings more than twice as normal cells and most of the glucose is converted into lactate, regardless of the presence of oxygen. In cancer patients, in addition to the above glycolysis changes, there is also insulin resistance. ${ }^{8,9}$

Changes in protein metabolism in cancer patients are characterized by decreased protein muscle synthesis, increased muscle protein catabolism and increased synthesis of acute phase proteins, such as C-reactive protein, as a response to inflammation. ${ }^{10,11}$ Insulin resistance leads to increased gluconeogenesis pathways and decreases protein muscle synthesis. Amino acids, especially alanine are broken down for precursors of glucose formation. ${ }^{9,12}$ Changes in lipid metabolism occur through increased lipolysis, decreased lipogenesis and adipogenesis, as well as increased fat oxidation.

The progression of lung cancer is influenced by the immune system, genetic factors and the inflammatory response. ${ }^{13}$ Increased inflammatory response is a component in the development of cancer cells that can be demonstrated through the increase of acute phase proteins (c-reactive protein), so that CRP can be relied as one of the parameters for predicting cancer cell progression and survival rates in patients with various solid cancers. ${ }^{14}$

Research on the intake of carbohydrates, proteins and fats with the development of cancer cells gives inconsistent results. ${ }^{15-16}$ Based on the above description, a study about correlation between carbohydrate, protein and fat intake with serum CRP levels as a parameter of cancer cell development in lung cancer patients at Dharmais Cancer Hospital Jakarta was conducted.

\section{Methods}

This cross-sectional study was conducted in Dharmais Cancer Hospital Jakarta from March to May 2017. The estimation of minimum sample size was calculated using the formula for a correlation study ${ }^{17}$ with a total number of 49 subjects required in this study. Subjects were obtained using consecutive sampling method.

All men and women aged above 18 years old, diagnosed with lung cancer, stage IIIB-IV, currently not receiving any therapy were included in this study. Those who agreed to participate in this study were asked to sign the informed consent. The exclusion criteria were the patients who had chronic liver disease, chronic kidney disease, diabetes mellitus, and after injury.

Data were collected through interviews, anthropometric measurements and blood sampling. Interviews were conducted to determine the characteristics of subjects. Macronutrients intake was obtained by using a semi-quantitative Food Frequency Questionnaire (FFQ). The FFQ was used to estimate the macronutrient usual intake in the past one month. Anthropometric measurements was performed by doing height measurement using Microtoise Stature Meter and weight measurement using $S E C A^{\circledR}$ electrodigital scale. The serum levels of CRP were examined using COBAS C311 using immunoturbidimetric assay.

Data was processed using the program Statistical Package for Social Sciences (SPSS) for Windows version 20. The normality of data distributions was analyzed using Shapiro-Wilk test. If $p<0.05$ data were normal distributed and were presented as mean \pm standar deviation, otherwise data were presented as median (minimummaximum). The correlation of carbohydrate, protein and fat intake with CRP serum were analyzed by Spearman rank collection test. 


\section{Results:}

\section{Subjects characteristics}

The characteristics of the subjects were summarized in Table 1. The mean age of subjects was $55.82 \pm 12.26$ years old, most of them were men. A total of $67.4 \%$ subjects have middle low education level and $79.6 \%$ have incomes above the minimum wage. Cancer histopatology were $95.9 \%$ non-small cell lung cancer (NSCLC). About 79.6\% subjects were in stage IV and $57.1 \%$ subjects had smoking history. Nutritional status assessment used body mass index (BMI) parameters based on Asia Pasific classification. There were $36.7 \%$ normoweight subjects and $20.4 \%$ underweight subjects.
The median energy intake of the subjects were 1740.5 (207.5-2527.9) kcal/day, with $53.1 \%$ subjects showed that energy intake still below ESPEN recommendations ( $30 \mathrm{kcal} / \mathrm{kgBW}$ per day). The average carbohydate intake were $59.59 \pm$ $8.11 \%$, with $75.5 \%$ subject at range of $45-65 \%$ carbohydrate from total energy. Mean protein intake were $63.65 \pm 25 \mathrm{~g}$ per day or $15,53 \pm 3,83 \%$ of total energy intake. Mean fat intake were 46.57 +22.62 g per day or $24.73 \pm 6.7 \%$ of total energy intake.

Median serum CRP levels were $23.82 \mathrm{mg} / \mathrm{L}$ $(0.30-207.29 \mathrm{mg} / \mathrm{L})$, with $61.2 \%$ of subjects having serum CRP levels $>10 \mathrm{mg} / \mathrm{L}$ (Table 2)

Table 1 Characteristics of subjects $(n=49)$

\begin{tabular}{lc}
\hline \multicolumn{1}{c}{ Variabel } & Value \\
\hline Age, (year) & $55.82 \pm 12.26 *$ \\
Sex, n (\%) & $31(63.3 \%)$ \\
Men & $18(36.7 \%)$ \\
Women & \\
Education, n (\%) & $12(24.5 \%)$ \\
Low & $21(42.9 \%)$ \\
Middle & $16(32.7 \%)$ \\
High & \\
Income, n (\%) & $10(32.7 \%)$ \\
Below minimum wage & $39(79.6 \%)$ \\
Above minimum wage & \\
Smoking history, n(\%) & $21(42.9 \%)$ \\
Never smoked & $28(57.1 \%)$ \\
Smoking & \\
Body mass index, n (\%) & $10(20.4 \%)$ \\
Underweight & $18(36.7 \%)$ \\
Normoweight & $10(20.4 \%)$ \\
Overweight & $7(14.3 \%)$ \\
Obese 1 & $4(8.2 \%)$ \\
Obese 2 & \\
Histopatology, n(\%) & \\
NSCLC & $47(95.9 \%)$ \\
SCLC & $2(4.1 \%)$ \\
Stage, n (\%) & \\
IV & $10(20.4 \%)$ \\
\hline
\end{tabular}

*Mean \pm standard deviation ** Median (minimum value - maximum) 
Table 2 Serum CRP level

\begin{tabular}{lc}
\hline \multicolumn{1}{c}{ Variabel } & Value \\
\hline Serum CRP level, mg/L & $23,82(0,30-207,29)^{* *}$ \\
$\leq 10 \mathrm{mg} / \mathrm{L}, \mathrm{n}(\%)$ & $19(38,8 \%)$ \\
$>10 \mathrm{mg} / \mathrm{L}, \mathrm{n}(\%)$ & $30(61,2 \%)$ \\
& \\
Stage IIIB & $14,46(0,30-141,17)^{* *}$ \\
Stage IV & $23,82(1,23-207,29)^{* *}$ \\
\hline$* *$ Median $($ Minimum
\end{tabular}

** Median (Minimum - Maksimum)

In this study, we did not find significant correlation

symptoms or showing unspecific symptoms, so between carbohydrate, protein and fat intake with serum CRP levels. (Table 3)

lung cancer was diagnosed when the disease has been in an advanced stage. ${ }^{21}$

Table 3 Correlation between carbohydrate, protein and fat intake with serum CRP levels $(n=49)$

\section{Variable}

Carbohydrate intake to total energy (\%)

Protein intake to total energy (\%)

Fat intake to total energy (\%)

${ }^{+}$Spearman rank correlation test

\section{Discussions}

In this study, the number of male subjects were more than women with a ratio of $1.8: 1$, with average age of the subjects of this study was 55.83 \pm 12.62 years. Study by Sutandyo ${ }^{18}$ conducted at the Dharmais Cancer Hospital found similar results to the male: female ratio $=3.1: 1$ and the mean age of the patients were 58 years. A total of $57.1 \%$ of subjects in this study had a history of smoking. This is different from the theory that $90 \%$ of lung cancer incidence is associated with smoking. ${ }^{19}$ This difference may be due to a decrease in the prevalence of smoking and the presence of other risk factors that can cause lung cancer, such as air pollution, prolonged exposure to carcinogenic substances. ${ }^{19}$ Based on data of cancer stage distribution, most of research subjects are in stage IV. Similar results were also obtained in the Sanchez-Lara study. ${ }^{20}$ This was consistent with the prevalence of advanced lung cancer higher than the early stages. This condition occured because in the early stages, lung cancer often does not show
Variable Serum CRP

$\begin{array}{cc}\mathrm{r} \text { value } & \mathrm{p} \text { value } \\ 0.015^{+} & 0.919 \\ -0.165^{+} & 0.257 \\ & \\ 0.003^{+} & 0.986\end{array}$

Median total energy intake of the subjects in this study were 1740.5 (207.5-2527.9) kcal per day or $29.68+10.67 \mathrm{kcal} / \mathrm{kgBW}$ per day. A total of $53.1 \%$ of subjects showed total energy intake under the recommendation of ESPEN. In this study, $42.9 \%$ of subjects were found to have protein intake below $1 \mathrm{~g} / \mathrm{kg}$ BW per day with average protein intake of $63.65 \pm 25 \mathrm{~g}$ per day or $1.14 \mathrm{~g} / \mathrm{kg}$ BW per day, obtained by dividing total protein intake per day per subject with actual body weight. Around $57.1 \%$ of subjects in this study had low fat intake $(<25 \%)$ with an average fat intake of $24.73 \pm$ $6.7 \%$ of total energy intake per day. A few reasons that can cause low energy intake in cancer patients including the decrease in appetite due to the role of pro-inflammatory cytokines in inhibiting the orexigenic pathway neuropeptide $\mathrm{Y}$ and stimulate anorexigenic $\alpha$-MSH pathway, nausea, satiety and chemosensory disorders such as persistent bad taste in the mouth, taste distortion, and heightened sensitivity to odors that often occurs in patients with advanced cancer. ${ }^{10,22}$ 
Serum CRP levels can be relied upon as one of the parameters for predicting cancer cell progression in patients with various solid cancers. ${ }^{14}$ This study found no correlation between carbohydrate intake to total energy $(p=0.919)$ with serum CRP levels. In contrast to studies conducted by Ho et $\mathrm{al}^{23}$ using tumor size in mice to assess cancer cell progression, there was a significant positive correlation between low carbohydrate intake $(15 \%$ of total daily intake) and tumor size $(\mathrm{p}<0.05)$. In this study, in addition to using tumor size, insulin levels and lactate levels are also used as a parameter of cancer development. There was positive correlation between low carbohydrate diet with insulin level and lactate level $(\mathrm{p}<0.05)$. The difference in outcomes between these two studies may be due to low carbohydrate intake, parameters used to assess tumor progression, type and stage of cancer. Percentage of carbohydrate intake used was $15 \%$, whereas in this study the average carbohydrate intake of the subject was $59.59 \pm$ $8.11 \%$.

This study has not proved the correlation between protein intake to total energy $(p=0.257)$ with serum CRP levels. Similarly, a study conducted by Lima et $\mathrm{al}^{24}$ found no association between protein intake and serum CRP levels $(p>0.05)$ in 30 gastrointestinal cancer patients. The study by Stobaus et $\mathrm{al}^{25}$ in 285 cancer patients with chemotherapy found that a low protein intake group $(<1 \quad \mathrm{~g} / \mathrm{kg} \quad \mathrm{BW})$ showed a significant difference in mortality $(p=0.024)$ compared with patients from the high protein intake group $(\geq 1 \mathrm{~g} /$ $\mathrm{kg} \mathrm{BW}$ ) and low protein intake is associated with fatigue and nausea/vomiting. The results of study conducted by Stobaus et al indicate that protein intake is good for supporting cancer patients.

This study has not proved the correlation between fat intake to total energy with CRP levels $(p=0.986)$. In contrast to a study conducted by Fontana et $\mathrm{al}^{15}$ found a significant association between fat intake and CRP levels $(p<0.027)$. In the study of Fontana et al, a significant relationship between fat intake with levels of IGF-1 $(p<0.003)$ and leptin levels $(\mathrm{p}<0.027)$ was also discovered. IGF-1 is mainly regulated by dietary intake to stimulate cell proliferation and inhibit cell death, so IGF-1 can support tumor development.
CRP levels are influenced by many factors. ${ }^{26-27}$ Some have been controlled such as acute infection, chronic illness, acute trauma and pregnancy. But there are still those that have not been controlled like allergic complication of infection and inflammatory diseases. Between macronutrients with inflammatory levels in this study using serum CRP level as a marker, chronic inflammatory biomarkers may be more meaningful when associated with intake, since intake is a long-term exposure factor.

In a further stage-based analysis, we did found in stage IV cancer patient there was a negative correlation but not significant between protein intake to total energy and serum CRP levels $(\mathrm{r}=-0.293$ and $\mathrm{p}=0.070)$ as well as fat intake to total energy and serum CRP levels $(r=-0.060$ and $\mathrm{p}=0.717$ ). From these findings, we further research using a larger number of subjects.

In conclusion, the results of this study can not prove that there is a correlation between carbohydrate, protein and fat intake with serum CRP level in lung cancer stage IIIB-IV. Further study regarding the association of macronutrient intake with serum CRP level using equally distributed subjects according to cancer stage is necessary. Early detection on malnutrion and early nutrition therapy, education and counseling are given to patients and their family to prevent malnutrition, which potentially increased morbidity and mortality in advanced cancer patient.

\section{Conflict of Interest}

Authors declared no conflict of interest regarding this study.

\section{Open Access}

This article is distributed under the terms of the Creative Commons Attribution 4.0 International License (http://creativecommons.org/licenses/by/4.0/), which permits unrestricted use, distribution, and reproduction in any medium, provided you give appropriate credit to the original author(s) and the source, provide a link to the Creative Commons license, and indicate if changes were made. 


\section{Acknowledgement}

We would like to acknowledge all staff of Poliklinik Onkologi-1 and Instalasi Gizi of Dharmais Cancer Hospital who had helped this study.

\section{References}

1. GLOBOCAN. Estimated cancer incidence, mortality and prevalance worldwide in 2012, International Agency for Research on Cancer, World Health Organization 2012. http://globocan.iarc.fr/Pages/fact_sheets_cancer .aspx (accessed 4 October 2016).

2. Komite Nasional Penanggulangan Kanker (KPKN). Panduan nasional penanganan kanker paru. Kementerian Kesehatan Republik Indonesia, 2015

3. Santarpia L, Contaldo F, Pasanisi F. Nutritional screening and early treatment of malnutrition in cancer patients. J Cachexia Sarcopenia Muscle 2011;2:27.

4. Ross PJ, Ashley S, Norton A, Priest K, Waters JS, Eisen T, et al. Do patients with weight loss have a worse outcome when undergoing chemotherapy for lung cancers. British journal of cancer 2004 May;90(10):1905-11.

5. Cutsem, E. Van, Arends J. The causes and consequences of cancer-associated malnutrition. European Journal of Oncology Nursing 2005 Dec;9.

6. Balkwill FR, Capasso M, Hagemann T. The tumor microenvironment at a glance. J Cell Sci 2012;135:5591.

7. Beloribi-Djefaflia S, Vasseur S, Guillaumond F. Lipid metabolic reprogramming in cancer cells. Oncsis 2016;5:189.

8. Warburg O, Wind F, Negelein E. The metabolism of tumors in the body. J Gen Physiol 1927;8:519-30.

9. Djiogue S, Kamdje AHN, Vecchio L, Maulilio JK, Farahna M, Aldebasi $\mathrm{Y}$, et al. Insulin resistance and cancer: the role of insulin and IGFs. Endocr Relat Cancer 2013;20.

10. Donohoe CL, Ryan AM, Reynolds JV. . Cancer cachexia: mechanisms and clinical implications. Gastroentral Res Pract 2011; 2011.

11. Porporato PE. Understanding cachexia as a cancer metabolic syndrome. Oncsis 2016;5:e200
12. Lieberman M, Marks AD, Peet A. Carbohydate Metabolism. In: Mark's Basic Medical Biochemistry A Clinical Approach 4th edition. Philadelphia: Lippincott Williams \& Wilkins; 2013.

13. Hanahan D, Weinberg RA. Hallmarks of cancer: the next generation. cell 2011 Mar;144(5):646-74.

14. Roxburgh CSD, McMillan DC. Role of systemic inflammatory response in predicting survival in patients with primary operable cancer. Future Oncol 2010;6(1):149.

15. Fontana L, Klein S, Holloszy JO. Long-term low-protein, low-calorie diet and endurance exercise modulate metabolic factors associated with cancer risk. Am J Clin Nutr 2006;84:1456.

16. Freedland SJ, Mavropoulos J, Wang A, Darshan M, Demark-Wahnefried W, et al. Carbohydrate restriction, prostate cancer growth, and the insulin-like growth factor axis. Prostate 2008;68:11.

17. Madiyono B, Moeslichan S, Sastroasmoro S, Budiman I, Purwanto SH. Perkiraan besar sampel. Dalam: Sastroasmoro S, Ismael S, editor. Dasar-dasar metodologi penelitian klinis. Edisi ke-4. Jakarta: Sagung Seto 2011;348-81

18. Sutandyo N. Epidemiological data and survival of lung cancer in Indonesia. Dharmais cancer hospital, Indonesia, 2015

19. Alberg AJ, Brock MV, Ford JG, Samet JM, Spivack SD. Epidemiology of lung cancer. Chest 2015;143(5): e1s-e29s

20. Sanchez-Lara K, Turcott JG, Juarez E, Guevara $\mathrm{P}$, Nunez-Valencia C. Association of nutritional parameters including bioelectrical impedance and systemic inflammatory response with quality of life and prognosis in patients with advanced non-small-cell lung cancer: a prospective study. Nutr Cancer 2012;64:526.

21. Perhimpunan Dokter Paru Indonesia. Kanker paru pedoman diagnosis \& penatalaksanaan di Indonesia. Edition 2015. Jakarta, Markindo Anugerah Citra Pratama, 2016

22. Hutton JL, Baracos VE, Wismer WV. Chemosensory dysfunction is a primary factor in the evolution of declining nutritional status and quality of life in patients with advanced cancer. J Pain Symptom Manage 2007;33:156.

23. Ho VW, Leung K, Hsu A, Luk B, Lai J, Shen $\mathrm{SY}$, et al. A low carbohydrate, high protein diet slows tumor growth and prevents cancer initiation. Cancer Res 2011;71(13):4484. 
24. Kv, d.L. (Gomes), Maio R. Nutritional Status, systemic inflammation and prognosis of patients with gastrointestinal cancer. Nutr Hosp 2012;27(3):707.

25. Stobaus N, Muller MJ, Kupferling S, Schulzke J, Norman K. Low recent protein intake predicts cancer-related fatigue and increased mortality in patients with advanced tumor disease undergoing chemotherapy. Nutr Cancer 2015;67(5):818.

26. Heikkila K, Ebrahim S, Lawlor DA. A systematic review of the association between circulating concentration of $\mathrm{C}$ reactive protein and cancer. J Epidemiol Community Health 2007;61:824.

27. Pepys MB, Hirschfield GM. C-reactive protein: a critical update. J Clin Invest 2003;111:1805. 